\title{
Crisis survival strategies: how a hotel survives during the Covid-19 pandemic
}

\author{
Musadad
}

Tour and Travel Business Study Program, Riau University

musadad@lecturer.unri.ac.id

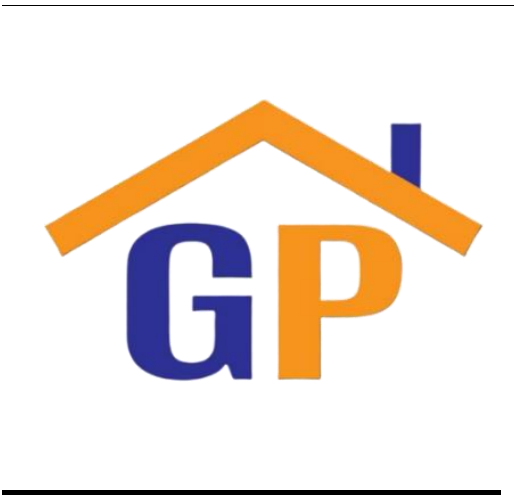

Article History

Received on 30 November 2020

$1^{\text {st }}$ Revision on 8 January 2021

$2^{\text {nd }}$ Revision on 24 January 2021

Accepted on 28 January 2021

\begin{abstract}
Purpose: This study identified and explored the strategies developed by a four-star hotel in Central Java Province - Indonesia for surviving the Covid-19 pandemic.

Research methodology: This qualitative study collected data from an in-depth interview with the hotel's Head of FO Department, which were analysed inductively.
\end{abstract}

Results: The hotel focused its survival strategies on four areas or aspects, including organisational targets, human resources, products and services, and marketing communication.

Limitation: This study is limited in two ways, i.e. data collection method and the number of informants.

Contribution: This study contributes to enriching the strategies for mitigating the disastrous impacts of the Covid-19 pandemic on the hotel business.

Keywords: Covid-19, Pandemic crisis, Survival strategies

How to cite: Musadad. (2020). Crisis survival strategies: how a hotel survives during the Covid-19 pandemic. Journal of Sustainable Tourism and Entrepreneurship, 1(3), 269-278.

\section{Introduction}

"Its damage has set the world in overdrive, searching to find solutions and innovative strategies to overcome a tough time." This is one concluding statement in the Covid-19 Research Report by Bloom Consulting (2020) to illustrate how massive and destructive the impact of the Covid-19 pandemic is. No other way to deal with it other than to formulate and execute problem-solving and creative strategies. The world is shocked by Covid-19. People do not expect a massive crisis due to the virus. The fast-spreading virus has caused people to do social distancing, which means they must avoid the crowd. Consequently, they are warned to stay away from others since the virus could infect them. Once someone is infected, he might die, sooner or later. Although the infected one survives, he or she could not be as fit as before. Not only humans who become victims of this crisis, but companies are also suffering or even dying. This is because their customers are reluctant to go outside to buy or enjoy their products. This means the demand goes down rapidly. The loss of customers is a disaster for a business. In general, companies are suffering from community lockdowns, social distancing, stay-at-home orders, and travel and mobility restrictions (Bartik et al., 2020).

One of the most suffered industries during the pandemic crisis is the hotel business. This industry cannot receive guests as many as before the pandemic. The number of guests is decreasing significantly as people prefer staying at home. People are also afraid to go out for eating out or travelling. These make hotels are at stake. Consequently, they have to formulate and execute strategies to respond to the pandemic crisis. Therefore, it is not too exaggerated to call their measures "survival strategies" as they are affected severely that almost collapse. Hotels, restaurants, and entertainment enterprises are suffering. The hotel occupancy rate decreases significantly as people are warned to stay at home. People are afraid to eat out and have fun outside. It is a tough situation for the hospitality business. Hence, they have to make strategies for at least attracting people to feel safe 
when they stay or come to their places. They create special promotions by giving discounts. They also try to ensure the customers that their places are safe by applying health protocols.

The current Covid19-pandemic can be categorised as a crisis, rather than a risk, as, according to Pearson and Clair (1998), a crisis is unpredictable, has vast impacts that can threaten an organisation's sustainability, has ambiguous causes and resolutions, and requires a quick response. All these characteristics of a crisis fit with the Covid-19 pandemic. The Covid-19 pandemic is unpredictable as the hospitality businesses are shocked by it. The virus pandemic has a low probability. As a result, many hospitality enterprises are not ready to face it, creating unmeasurable and unreliable steps. Besides, it has vast impacts as the pandemic has significantly decreased the number of guests or customers. The hospitality industry is dependent much on the number of guests since it is a people-topeople business. Fewer guests are disastrous to the business, so this pandemic has enormous impacts. The causes of the virus are ambiguous in the sense that they are still debatable. What country did first spread the virus, including where and when the virus first appeared. The solution measures are also debatable, especially the health protocols and the tests. Lastly, the hospitality business has to respond swiftly to the pandemic to keep the business viable. If a hospitality organisation does not respond to this pandemic fast, it might suffer severely and then collapse.

The abundant number of hospitality businesses who are confused about the pandemic measures show that hospitality enterprises tend to be unaware of the pandemic crisis management. They are more familiar with management for common crises such as fire, earthquake, terrorism, loss of informational data, and others. Therefore, hospitality businesses must have a pandemic crisis management for anticipating pandemic in the future by minimising the huge impacts. As the most suffered industry, the hospitality business would be more prepared to contend with the Covid-19 once it has pandemic crisis management.

To identify and explore the hotel survival strategies during the Covid-19 pandemic, the researcher conducted an in-depth interview with a front office manager in a hotel in Central Java Province, Indonesia. As the head of a hotel department, the interviewee knew much about his hotel as he has been in the hotel industry for almost 7 years.

\section{Literature review}

Maffioli (2020) explained that the rate of speed and scale of coverage of the spread of the Covid-19 virus exceeded the virus outbreak cases in the previous decade. Covid-19 caused the world community's response to be very different from previous cases of virus outbreaks such as the H1N1 virus in 2009-2010, the 2014 Ebola virus in West Africa, or the Latin American Zika virus in 20152016. Another thing that distinguishes it is China's status, which is the starting point for the spread of Covid-19, a country with the world's number two economic power so that it has a broad impact on business interactions many partner countries.

\subsection{The impact of Covid-19 pandemic}

The Covid-19 has brought severe economic impact to countries in the world. Khan and Faisal (2020) examined the impact of Covid-19 on the Chinese economy by studying 15 articles in various journals and reports that discuss studies on related themes. They found that the lockdown policy of Wuhan City, followed by the quarantine of other cities and provinces had reduced and even stopped various activities of the community, students, students, workers in public areas, cessation of manufacturing, land transportation, flight routes and the postponement of a lot of development and the delay in investment, as well as the activities of the financial sector, banking and export-import caused a decline in growth rate of $2 \%$ from the $6 \%$ position before the Covid- 19 pandemic.

Baldwin and Tomiura (2020) found a tendency that the Covid-19 pandemic At the beginning of the Wuhan city lockdown incident with various reported events, had a negative impact on news and business interactions for residents and networks of the city of Wuhan, Hubei Province, China and also when the virus spread throughout. mainland China. 
Baldwin and Mauro (2020) stated that in the subsequent developments of Covid-19, it would have a negative effect on areas and countries affected by Covid-19, but had a further impact on other countries was related to the economic value chain. When the virus spreads beyond mainland China (Mainland China), the effect is even wider. Especially when the number of countries that become victims continues to increase, especially countries that have economic power such as China, USA, Germany, Italy, Japan and South Korea. Koshle, et al (2020) examined the impact of the Corona virus on businesses in India and found that the trade sector caused losses of not less than USD 348 million due to the economic slowdown and policies' consequences.

In the hotel industry, Jiang \& Wen (2020) claim that the Covid-19 pandemic has changed hotels' function and survival worldwide. Therefore, now is the time for practitioners and academics to carefully examine the impact of this crisis and find solutions for the hotel industry, as well as advance the knowledge base to help hotels recover from the Covid-19 pandemic. In essence, according to Jiang \& Wen (2020) there are three main issues in the hospitality industry amid the Covid-19 pandemic that needs to be paid attention to by practitioners and academics, namely AI and robotics, hygiene and cleanliness, and health and healthcare.

\subsection{Crisis management}

Pearson and Clair (1998) define a crisis as generally defined as an ambiguous situation that is a major threat to the survival of an organisation, whose causes and effects are unknown, that there is little time to respond, and requires decisions that will result in changes for the better or the bad. Therefore, a crisis must be managed to mitigate its huge impact. Pearson and Clair (1998) define crisis management as a systematic effort to avoid organisational crises or manage crises. Coombs \& Holladay (2010) added that crisis management is an effort to prevent or reduce the negative outcome of a crisis through three stages, namely pre-crisis, response to the crisis, and post-crisis to protect organisations and stakeholders.

So, the essence of crisis management is an effort to reduce the uncertainty and risk factors to the lowest possible level, thereby presenting as many certainty factors as possible. In fact, what is called crisis management begins with the step of seeking as much information as possible about alternatives, as well as on probabilities, even if possible regarding the certainty of occurrence, so that decisionmaking regarding planned steps to be taken can be based more on as much as possible and completely. as possible and as accurate as possible the information. Of course, strived from reliable sources (reliable), while the material also carries sufficient weight of reason. The awareness of the impact caused by the crisis as well as the weakness in anticipating the arrival of a crisis, makes it necessary to take anticipatory steps in a framework called crisis management. Crisis management differentiates crisis situations into pre-crisis and crisis.

Therefore, during the process of developing crisis management, it is vital to identify the type of crisis in different situations and use a variety of different crisis management strategies. It should be noted that predicting crises is very difficult, but identifying the types of crises is very easy and can be grouped. Lerbinger (1997) categorises there are seven types of crisis: a) Natural disasters, b) Technological crisis, c) Confrontational crisis, d) Crisis of Malevolence, e) Crisis of Organisational Misdeeds, f) Workplace violence, and g) Rumors.

\section{Research methodology}

This study belongs to a qualitative study. The primary data was collected from an in-depth interview with the hotel's Head of FO Department. The collected data was then analysed inductively using three phases as proposed by Miles and Huberman (2014), i.e. data reduction, data presentation, and conclusion.

This research is included in qualitative research, where this research is based on the research focus that is reviewed and in advance of the patterns and procedures that the researcher passes. This 
research examines words, conducts studies on the circumstances experienced, makes a complex illustration or picture, and a report compiled from respondents' views (Creswell, 2007). This research was conducted at a 4-star hotel in Central Java Province, Indonesia. Primary data in this study were obtained through observational interviews and documentation, while secondary data was obtained through supporting documents such as financial reports, occupancy data, and others.

To collect data about the survival strategy of a hotel amid the Covid-19 pandemic, the data collection techniques that researchers use include:

1). Observation

Observation is a form of data collection by recording and observing in a designed manner regarding the phenomena seen in the study's objects. From these observations, researchers will systematically record the symptoms that appear on the surface related to the survival strategy amid the Covid-19 pandemic.

2). Interview

The interview is a question-and-answer process in research that takes place orally through dialogue or conversation. In this study, the key informant was the front office department manager. He is already very experienced in the hospitality sector and knows details about hotel operations.

3). Documentation

The technique of collecting data with documentation is the collection of data obtained through documents. Documents can be in the form of writings, pictures, and related party files related to research. Researchers' documentation method in conducting this research is used to collect data from written material sources, namely in the form of official hotel documents or archives.

For data analysis, Miles and Huberman (2014) show that the data analysis activities carried out in this research are in the form of analysis before it occurs in the field and after it occurs. Data analysis activities in this study consisted of analysis before in the field and during the field. According to Miles and Huberman (2014), there are three kinds of activities in qualitative data analysis, namely:

1). Data reduction

Data reduction focuses on simplification, determination procedures, summarises and changes to raw data that can be seen from written records that occur in the field. Which is the result of data reduction, namely in the form of interviews, documentation and observations.

2). Data display

Data presentation is meant by presenting data in the form of a matrix, network, chart or graph, table, and others. According to Miles and Huberman, the data display is a depiction of a set of detailed information that puts the possibility that there is a conclusion and taking action. Therefore, with the presentation of data, it will make it easier for the research conducted by researchers to understand the extent of the data obtained and what happened. They can choose steps to take action to do next.

3). Verification

It will reveal the meaning of the data collected in this research process. These conclusions will be verified again because the data is a conclusion that is still in doubt, vague and rigid. For conclusions to be drawn and taken not to deviate, it is necessary to verify where it can be done by looking back at data reduction or data presentation.

\section{Results and discussions}

The in-depth interview was focused on the strategies implemented by the hotel for surviving the pandemic crisis. At least four areas are identified and explored as part of the hotel survival strategies, which will be described in the following sections. These include organisational targets, human resources, products and services, and marketing communication. These four aspects of a hotel business are the focus of this paper.

\subsection{Organisational target}

The Covid-19 pandemic has pushed business enterprises to make internal changes. The department head I interviewed with said that his hotel was forced to adjust its revenue target. The goal setting is shifted from being a profitable organisation into a survived one. This makes sense since the pandemic 
has brought a severe impact on the hotel. It has to deal with a limited number of guests and a rise in spending. The supply does not meet the demand.

The main goal of the company is to gain profits. The definition of operating profit is the difference between realised income arising from transactions during one period and the costs associated with these costs. The net income or net profit is an excess of income against the expenses that occur. So, profit is the excess of income over expenses during an accounting period. Meanwhile, the understanding of profit observed by the current accounting structure is the difference between the measurement of income and costs.

The profit consists of four main elements, namely revenue, expense, gain, and loss. According to Stice et al (2004), the elements of profit are as follows: 1) Revenue is the inflow or other increase of an entity's assets or payment of its obligations (or a combination of both) from the delivery or production of a good, giving service, or other activity that is the entity's largest or first business undertaking. 2) Expenses are outflows or other uses of assets or the incurrence of liabilities (or a combination of both) from the delivery or production of goods, the provision of services, or other activities that constitute the largest business or the first business undertaken by the entity. 3) Gain is an increase in equity or (net assets) from side or occasional transactions of an entity and from all transactions. Other events and conditions that affect the entity, except those that arise from the owners' income or investments. 4) Loss is a decrease in equity (net assets) from side or occasional transactions of an entity and from all transactions. Other events and conditions that affect the entity, except those that arise from the owners' income or investments.

Wiyasha (2010: 19) states that hotel revenue comes from the sale of rooms, food, beverages and other income (commonly called minor operated department sales such as telephones, laundry, dry cleaning, swimming pools and others). The costs and cost of goods are incurred for the cost of consumables in every part of the hotel, the cost of food and beverages, general and administrative costs, marketing costs, interest costs, depreciation and amortisation costs, human resource costs, maintenance costs for hotel physical facilities, energy costs and resulting profit/loss.

As we know, a business is run to make a profit. So, a profitable business will always be the goal of a company. Various efforts are made to achieve this goal. Indeed, the extent to which the profit target is set depends on certain factors. When everything is okay, then the profit target can be optimal, but the target would not be maximum when there are some weaknesses.

Being profitable is one of the company goals. Oracle (2012) claims that there four types of goal setting in a company, including improved shareholder value, greater profitability, increased revenue, and inspired innovation. To achieve these, there must be relevant and supportive elements. Nevertheless, the pandemic has caused irrelevant and unsupportive components to achieve the profit goal, for instance, the decreasing market and rise in spending. Therefore, it is understandable when the hotel sets a survival goal, not a profitable one, during the Covid-19 pandemic.

\subsection{Human Resources}

The next focus of the survival strategy performed by the hotel is related to human resources. It is commonly known that the workforce is one of the organisational costs. Human resources spend some funds for recruiting expenses, basic salary, employment taxes, benefits, space, and other equipment (Hadzima, 2005). As a consequence, a higher number of employees means higher cost and vice versa. These three issues faced by the hotel in terms of human resources.

First, Proportion of Staff. The hotel occupancy rate was below 30\% from early April to August. Even though there were fewer hotel guests, the hotel still operates. The management decided to keep the hotel open with some considerations, one of which is always to be ready if guests arrive at any time. In its operation, this hotel applies a staffing guide, i.e. scheduling and control tool to determine the total labour hours, the number of employees, and the estimated labour expense needed to operate the 
housekeeping department when the hotel is specific occupancy levels (O'Fallon \& Rutherford, 2011). There are two types of staff, namely:

1. Fixed staff positions are those that must be filled regardless of the volume of business. These positions are generally managerial and administrative. E.g. executive housekeeper, assistant exec. housekeeper, supervisor (day shift), department clerk (day and afternoon shift).

2. Variable staff positions are those that are filled according to the changes in the occupancy level. E.g. room attendants (day and afternoon shift), house persons (day and afternoon shift), inspectors, lobby attendants.

Second, Hotel Operations. With less income, the hotel management decided to continue operating. With the enactment of the government policy on domestic flights, in September the hotel starts having guests, with a maximum occupancy of $30 \%$. The staff take turns coming to work, focusing on maintenance, deep cleaning, and joining training/adaptation of new normal procedures. Since the room occupancy ranges from $0-30 \%$, all staff perform other departments or sections' tasks. For example, the HR Manager helps to fold hotel linens in the laundry room because this section is very understaffed when there are guests.

Like other departments, a receptionist for the FO Department is also in charge of maintaining the lobby area's cleanliness, which is originally the public area attendant's job. In addition, he or she is also in charge of maintaining the security of the lobby area, which is originally the security team's duty. Something similar happens in other departments, a chef is not only in charge of cooking, but he is also required to clean his own equipment because there is no longer a stewarding team, but because his position requires special expertise, his existence cannot be replaced by staff from other departments.

Third, Staff Income and Benefits. In the hotel, the staff's income does not only come from salaries. There is also a payroll component that comes from service. In addition to $10 \%$ tax, guests are also required to pay services for $10 \%$ of all their expenses when staying at the hotel. In normal situations, this service can be 3 or 4 times greater than the basic salary of the hotel staff. The higher the occupancy rate, the higher the service charge distribution received by the staff. Automatically since April, the staff does not receive this service charge distribution. Without income, the company still pays the full salary to employees for two months (April-May), but only $50 \%$ of the basic salary is paid to the staff from June to October. This amount is below the regional minimum wage. Other benefits like aeroplane tickets are also eliminated.

The interviewee (department head) admitted that his hotel performed some tactics for minimalising the workforce cost, i.e. first, by reducing the number of employees. The hotel currently employs $50 \%$ of the total number of employees. Ideally, the number of bedrooms is equivalent to the number of employees. For example, when a hotel has 100 bedrooms, then there should 100 employees. The interviewee claimed that this number did not affect the hotel operations since the hotel's room occupancy is about $30 \%$. So, every technical work can still be handled by those workers.

The second tactic is to have more diverse types of workforce. The department head said that his hotel hired contract staff and daily workers and casual workers. The proportion is $50 \%$ of contract workers and $50 \%$ of daily and casual workers.

The third tactic is related to recruitment. Since the hotel is new, it still needs to recruit some new employees. The hotel hires employees who are laid-off by other hotels. These laid-off employees 
come back and stay in the city where the hotel is located or the surrounding cities. In this way, the hotel can get skillful employees with local wages.

Interestingly, the contract staff does not experience reduced salaries as they are the hotel's preopening team. Those who are suffering from reduced income are daily workers since the hotel's events are getting less. Their workdays only range from 13 to 18 days a month.

\subsection{Products and services}

Bartik et al (2020) claim that many hospitality businesses' survival heavily depends on increasing the demand for their services and products. Therefore, service and products are essential to gain customer trust. The manager whom the researcher interviewed said that there were no many changes in the tangible products. His hotel still maintains regular products. For example, the hotel still provides breakfast with various food and beverages. The swimming pool, MICE, and other facilities still operate. In short, the hotel continues to provide standard products to maintain its brand as a four-star hotel.

As in any manufacturing business, good service businesses use marketing to strengthen their position in selected target markets. However, because they differ from tangible products, services often require an additional marketing approach. In the product business, the product is simply placed on the shelf and waiting for the buyer to buy the product. However, in the service business, customers and employees interact directly with customers to create services. Thus, service providers must work to interact effectively with customers to create superior value during service delivery. In turn, effective interactions depend on service employees' skills upfront and on service production and support processes for these employees.

According to Wiyasha (2010) the characteristics of hotel products are as follows: 1) Guests are involved in the production process, for example when guests enjoy the food at a restaurant, 2) Samples cannot be used, products must be enjoyed directly by guests, 3) Services that are not sold on certain days cannot be saved and compensated for the next day's sales, 4) Guests as consumers must come directly to the location to enjoy guest products, 5) Inconsistent service quality, the same product prepared by different employees will produce different quality, 6) Hotel image is invisible, 7) Easily imitated or duplicated by competitors.

In terms of service, the hotel applies health protocol. This is to satisfy the increasing demands for safe and clean hotels. The health protocols are performed from the check-in, queuing, eating in the restaurant, until entering the room. The guests and staff have to wear plastic hand gloves, masks, and hand sanitiser provided by the hotel. All staff, including the receptionists, security staff, housekeepers are equipped with gloves, masks, face shields. The lobby is set with a social distancing layout. In the restaurant, the guests are not allowed to take the food by themselves. The capacity of the restaurant is reduced to $60 \%$. The waiter or waitress will pick the food for the guests to avoid frequently touched spoons. In addition, the room is equipped with a UV filter. The manager said that the hotel spent 14 million IDR or about 1000 USD to procure such equipment.

As the pandemic's tourist behavior is changing (Bloom Consulting, 2020), they will choose a hotel not only by paying attention to the facilities, location or price, but also the level of safety and cleanliness. Therefore, to make the hotel's guests more confident to stay in, the hotel has sought and gained a CHSE certificate. The CHSE (cleanliness, health, safety, and environmental sustainability) certification is the Ministry of Tourism of Indonesia's program to facilitate tourism-related businesses to have a standardised Standard Operating Procedure for health protocols.

\subsection{Marketing communication}

The last aspect addressed in the survival strategies of the hotel is related to promotion or marketing communication. The manager said that the situation is challenging to promote his hotel. Many promotional programs have been launched to attract more customers, but the results are so-so. This is 
not shocking since people are warned to stay at home and make social distancing. That is why the hotel relies much on the corporate and government segments and a little portion of walk-in guests.

Belch \& Belch (2006) defines Marketing Communication as a business process strategy that is used to develop, execute, evaluate, measure, a brand communication program within a certain period to consumers, customers, employees, and other targets for both internal and external audiences of the company. The goal is to gain brand benefits financially both in the short and long term and increase its value. So, marketing communication plays a role in promoting the products that will be offered so as to generate consumer interest in buying and using them, and this effort is made to achieve sales targets and branding of a company in increasing long relationships both in the eyes of print and electronic media and in the eyes of the wider community (consumers).

Marketing Communication plays a vital role for marketers. Without communication, consumers and society will not know the existence of products in the market. Therefore, marketing communication planning must be careful and calculated in managing funds because the costs incurred are not small. So, determining who is the target of communication will significantly determine the success of the communication itself. By determining the right target, the communication process will run effectively and efficiently.

Shimp (2003) shows the main forms or main dimensions of marketing communication as follows:

a. Personal selling is a form of communication between individuals in which salespeople inform, educate, and persuade potential buyers to buy company products or services. This sales effort is simplified by providing "introductory discounts" to retailers and convincing them through advertising, free sample products, and coupons to boost sales.

b. Advertising consists of mass communication through newspapers, magazines, radio, television and other media (billboards, internet etc.) or direct communication specially designed for inter-business (business-to-business) customers and end-users.

c. Sales Promotion (Sales Promotion) consists of all marketing activities that try to stimulate the action of buying a product quickly or the occurrence of purchase in a short time.

d. Sponsorship Marketing is an application to promote companies and their brands by associating a company or one of the brands with specific activities.

e. Publicity, including advertising, publicity describes mass communication; but also, unlike advertising, corporate sponsorship is usually done in the form of advertising time and space. Publicity is usually done in the form of news or editorial comments about the company's products or services. These forms are published in print or television for free because media representatives consider the information important and worthy of being conveyed to their audiences.

f. Point-of-purchase communication involves displays, posters, signs, and various other materials designed to influence the decision to buy at the place of purchase. In-store displays play an important role in attracting consumers to try product trial packaging.

The measures that have been taken to promote the hotel's products and services include, first, giving a discount. The amount can reach up to $60 \%$ of the published rate. A room rate of 900 thousand IDR or 65 USD will become 360 thousand IDR or 26 USD. The discount is published in the hotel's social media accounts or through the online travel agents. The second promotion uses the gimmick, for example, giving free dinner when booking through online travel agents or offering late check-out at the weekends.

In general, in this pandemic, the hotel relies heavily on online travel agents (OTAs) to communicate its promotion and perform distribution. The distribution here means where to book, i.e. through intermediaries (OTAs). The hotel cooperates intensively with three major OTAs in Indonesia, namely Traveloka, Tiket.com, and Pegi-Pegi. The commission fee for these OTAs ranges from $15 \%$ to $18 \%$. 


\section{Conclusion}

The destructive impact of the pandemic crisis is inevitable for the hotel business. Ready or not, willing or not, the hotels have to deal with this challenging situation. The hotel management has thought hard about formulating and taking measures to contend with the crisis. Some succeed, while some fail. The success of strategies depends relatively on the quality of the strategies themselves and the techniques and leadership to implement them.

A new hotel in Central Java Province, Indonesia, strategises four aspects or areas for its survival strategies. First, it has revised its organisational goals from being a profitable enterprise to a survivor during a pandemic crisis. It reduces daily costs to save hotel finance. Spending is pressed in such a way to maintain its cash flow.

Second, this hotel also tries to save costs by having only $50 \%$ of its normal number of employees. As a new enterprise that still needs some more workers, the hotel recruits laid-off employees to get a competent workforce but with the local minimum wage.

Third, several measures are performed to make customers assured that the hotel is safe and clean. Modifying products and services by applying health protocols is one way to respond to altered customer behavior. To make customers more confident about the cleanliness, health, safety, and environmental sustainability (CHSE), the hotel submitted a request for CHSE certification from the Ministry of Tourism and managed to get the CHSE certificate.

Fourth, this hotel launches various promotional programs to attract more customers, including giving high discounts, free dinner, and late check-outs. To execute these, the hotel makes intensive cooperation with three major online travel agents in Indonesia.

The current Covid-19 pandemic should be a turning point for this hotel. All experiences during the pandemic to survive can serve as "materials" to create pandemic crisis management. The management and the hotel owner can meet and discuss the crisis management plan's best measures. It should be suited to this hotel's characteristics as a crisis management model is not "one size fit for all". Some aspects, such as geography, target markets, human resources, and finance are different from one hotel to another. Generally speaking, after creating the most suited model for pandemic crisis management with its strategic measures, this hotel must determine the persons in charge as a crisis management team.

\section{Limitation and study forward}

This study is limited in two ways, i.e. data collection method and the number of informants. It only conducted an in-depth interview with only one key informant. Further studies are expected to have more informants and varied methods of data collection.

\section{Acknowledgement}

The author would express his gratitude for David Berry of Niagara College Canada who gave the inspiration to complete this study.

\section{References}

Baldwin, R. \& Mauro, B. W. (2020). Economics in the Time of Covid-19. CEPR PressVoxEU. org.

Baldwin, R. \& Tomiura, E. (2020). Thinking ahead about the trade impact of Covid-19. CEPR Press VoxEU. Org

Belch, G. E. \& Belch, M. A. (2006). Advertising and Promotion: An Integrated Marketing Communication Perspective: Mc Graw Hill, New York.

Bartik, A. W., Bertrand, M., Cullen, Z. B., Glaeser, E. L., Luca, M., \& Stanton, C. T. (2020). How are small businesses adjusting to Covid-19? Early evidence from a survey (No. w26989). National Bureau of Economic Research 
Bloom Consulting (2020). Covid-19 The impact on tourist behaviours. Retrieved from http://www.bloom-consulting.com

Coombs, W. T. and Holladay, S. J. (2010). PR Strategy and Application: Managing Influence. United States: Wiley-Blackwell

Creswell, J.W. (2007). Qualitative Inquiry and Research Design: Choosing among Five Approaches, 3rd Edition. Thousand Oaks, CA: Sage

Hadzima, J.G. (2005). How much does an employee cost? Starting Up: Practical Advice for Entrepreneurs.

Jiang, Y., \& Wen, J. (2020). Effects of Covid-19 on hotel marketing and management: A perspective article. International Journal of Contemporary Hospitality Management, 32(8), 2563-2573

Khan, N., \& Faisal, S. (2020). Epidemiology of Corona Virus in the World And Its Effects on The China Economy. Electronic copy available at: https://ssrn.com/abstract=3548292

Koshle, H., Kaur, R., Basista. R. (2020). Breakdown of Business and Workers in India, Impact of Corona Virus, 19 March, available at http://dx.doi.org/10.2139/ssrn.355754 4.

Lerbinger. 1997. The crisis manager: facing risk and responsibility, New York: Erlbaum

Maffioli, E. M. 2020, How is the World Responding to the 2019 Coronavirus Disease Compared with the 2014 West African Ebola Epidemic? The Importance of China as a Player in the Global Economy, Am. J. Trop. Med. Hyg., 00(0), pp. 1-2

Miles, M. B., Huberman, A. M., \& Saldana, J. (2014). Qualitative Data Analysis A Methods Sourcebook. Los Angeles: SAGE Publications, Inc

Oracle (2012). Goal-setting: A fresh perspective. An Oracle white paper. USA: ORACLE Taleo Cloud Service.

O'Fallon, M.J. \& Rutherford, D.G. (2011). Hotel Management and Operations (5th Ed.). Hoboken, NJ: John Wiley and Sons, Inc

Pearson, C.M. \& Clair, J.A. (1998). Reframing Crisis Management. Academy of Management Review, 23, 59-76.

Shimp, T.A. (2003). Advertising, Promotion and Supplemental Aspects of Integrated marketing Communications, Sixth Edition. Mason, Ohio: Thomson South Western.

Stice, E. K., Stice, J. D., Skousen, K. F. (2004). Intermediate Accounting, 15 th edition. SouthWestern College Pub

Wiyasha, I.B.M. (2010). Akuntansi Perhotelan. Yogyakarta: Andi Offset. 